REVISTA DE LITERATURA E CULTURA RUSSA

Sobre a preparação e a proibição da edição russa da obra de Jan Mukařovský, organizada por Iuri Lótman e Oliég Maliévitch

Around the preparation and prohibition of the Russian Edition of Jan Mukařovský's works edited by Yuri Lotman and Oleg Malevich

Autor: Igor Pilshchikov Universidade da California Los Angeles, California, Estados Unidos Autor: Mikhail Trunin Universidade de Tallinn Tallinn, Estônia

Edição: RUS Vol. 12. № 19 Publicação: Agosto de 2021 


\section{Sobre a preparação e a proibição da edição russa da obra de Jan Mukařovský, organizada por Iuri Lótman e Oliég Maliévitch ${ }^{1}$}

Igor Pilshchikov* Mikhail Trunin**

Resumo: No final dos anos de 1960, luri Lótman, um dos fundadores da Escola de Semiótica Tártu-Moscou, preparou, em cooperação com seus colegas, uma edição em dois volumes de escritos de Jan Mukařovský, um dos fundadores do estruturalismo literário tcheco e da estética semiótica. Embora Mukařovský alegasse lealdade ao marxismo já no início dos anos de 1950 e fosse considerado politicamente aceitável na URSS, tanto seu passado estruturalista quanto a bagagem estruturalista de Lótman eram alheios e suspeitos aos marxistas ortodoxos dominantes e às autoridades de censura soviéticas, especialmente depois da "Primavera Tcheca" de 1968. A edição russa de Mukařovský veio a lume só depois do colapaso da União Soviética (e da morte de Lótman). Baseado em vasta documentação de arquivo, este artigo oferece uma reconstrução detalhada da história da edição inicial não publicada.

\begin{abstract}
In the late 1960s, Yuri Lotman, a founder of the Tartu-Moscow Scool of Semiotics, prepared, in coperation with his colleagues, a two-volume edition of selected writings of Jan Mukařovský, a founder of Czech literary structuralism and semiotic aesthetics. Although Mukařovský claimed allegiance to Marxism as early as the 1950s and was considered politically acceptable in the USSR, both his structuralist past and Lotman's structuralist backround were too alien and suspicious for the ruling orthodox Marxists and Soviet censorship authorities, especially after the 1968 "Prague Spring". The Russian edition of Mukařovský saw the light of day only after the collapse of the Soviet Union (and Lotman's death). The article offers a detailed reconstruction of the history of the initial, unrealized edition based on numerous archival documents.
\end{abstract}

Palavras-chave: Mukařovský; Lótman; Oliég Maliévitch; Escola de Praga; Estruturalismo (Crítica Literária); Pressão ideológica na URSS Keywords: Jan Mukařovský; Yuri Lotman; Oleg Malevich; Prague School; Literary Structuralism; Ideological pressure in the USSR 
* Professor do Department of Slavic, East European and Eurasian Languages and Cultures, University of California, Los Angeles (UCLA), USA; e professor pesquisador do Humanitaarteaduste instituut, Tallinna Ülikool, Eesti; https://orcid.org/00000003-0153-6598; pilshch@tlu.ee

** Pesquisador do Humanitaarteaduste instituut, Tallinna Ülikool, Eesti. https://orcid.org/00000001-5307-9144; mikhail@tlu.ee

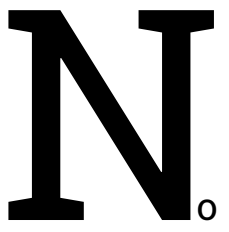

verão de 1969, um dos líderes do estruturalismo soviético, o professor titular da Universidade de Tártu Iuri Mikháilovitch Lótman (1922-1993), juntamente com seu amigo e coautor de Leningrado, um especialista em literatura tcheca, Oliég Mikháilovitch Maliévitch (1928-2013) e sua esposa Viktória Aleksándrovna Kamiénskaia (1925-2001), conhecida tradutora do idioma tcheco, apesentaram à editora moscovita Iskusstvo o projeto para publicação de uma coletânea em dois volumes com os artigos do clássico estruturalista tcheco Jan Mukařovský (1891-1975) com um grande aparato de comentários e um artigo introdutório intitulado "Jan Mukařovský, teórico da arte". Em meados dos anos 1960 ocorreu a fase mais importante da recepção da Escola de Praga por parte dos estrturalistas e semióticos de Tártu e Moscou. Em 1964, foi lançado em russo o Dicionário linguístico da Escola de Praga, de Josef Vachek; em 1967, saiu uma coletânea de traduções russas dos trabalhos linguísticos mais importantes do Círuclo de Praga. ${ }^{2} \mathrm{O}$ livro trazia textos do fundador da teoria e da estética semiótica da Escola de Praga e deveria vir na sequência dessa série. Contudo, não foi o seu destino vir a público naquela época. $O$ presente artigo, dedicado à história dessa edição não publicada, demonstra claramente tanto a disposição das forças ideológicas no final do período soviético quanto as particularidades do contexto científico da época. ${ }^{3}$

A intenção de organizar uma edição russa representativa dos trabalhos de Mukařovský partiu de Lótman e Maliévitch ainda em 1966. A proposta foi entregue à editora Progress que se especializou nas edições de autores estrangeiros, mas esta,

\footnotetext{
1 Este trabalho recebeu o apoio do Eesti Teadusagentuur (grant nr PRG319).

2 VACHEK, 1964; KONDRACHOV, 1967.

3 Sobre a influência conceitual de Mukářovský em Lotman ver PILSHCHIKOV, POSELIÁGUIN, TRUNIN, 2018, p. 54-61.
} 
segundo as memórias de Maliévitch, "não tinha pressa em implementar a proposta". Então, Lótman decidiu seguir outro caminho:

Em 1969, Iuri Mikháilovitch fechou um acordo sobre a edição em dois volumes de trabalhos escolhidos de Jan Mukařovský (volume total de 55 laudas) 4 com a editoria de estética da editora Iskusstvo de Moscou [...].

Entre 1969 e 1970, os dois volumes foram traduzidos por mim e por minha falecida esposa Viktória Aleksándrovna Kamiénskaia (segundo os termos do contrato, ditados por considerações práticas, eu retirei minha assinatura). Durante a elaboração dos dois volumes, eu me consultei constantemente com Iurmikh. ${ }^{5}$ No verão de 1970, Lótman leu e editou a tradução finalizada.

No outono, Iumikh e eu comentamos todo o texto traduzido. ${ }^{6}$ Isso aconteceu ao longo de duas ou três noites. Vika ficou sentada diante da máquina de escrever (com caracteres russos e tchecos), enquanto Iuri e eu ditávamos o texto das notas. Eu tinha as edições tchecas e russas de referência a mão, enquanto Iuri tirava quase tudo "da cabeça". Pressupunha-se que as correções factográficas seriam feitas posteriormente. Aliás nessa época o prefácio "Jan Mukařovský, teórico da arte" já havia sido escrito por Lótman, e tudo o que dizia respeito a esse tema foi elaborado teoricamente por ele. ${ }^{7}$

O plano da edição foi anexado à proposta, sendo que uma de suas variantes foi preservada no arquivo de Lótman:

\footnotetext{
4 Em russo "a. l." (ávtorski list, página do autor, em português): unidade de medida de volume de um material composto pelo autor, tradução, organização ou revisão. Uma unidade equivale a 40 mil caracteres com espaço. (N. da T.)

5 Apelido de luri Lótman, formado pelas primeiras letras de seu primeiro nome e patronímico. Cunhado pelo seu amigo e colega de trabalho Boris Fiódorovitch Egorov (1926-2020), foi amplamente utilizada.

6 A estrutura do comentário de Lótman foi descrita em carta a Maliévitch (verão de 1970): "Concordo com a sua opinião sobre o tipo de comentário: para os artigos, inicialmente uma caracterização geral (breve) do trabalho, depois observações linha a linha. Os comentários estão misturados quanto ao tipo: teóricos e biobibliográfico-crítico-históricos, que introduzem situação, polêmica, bem como ecos sociais e literários e contexto geral. Eu escreverei o primeiro; Vossa Senhoria, o último. Escreveremos separadamente, depois misturaremos como um baralho de cartas (JLSV, f. 4.4 [0. M. Maliévitch], s.n.).
}

7 MALIÉVITCH, 2009. 
O primeiro volume irá incluir obras de Mukařovský que tratam de questões gerais de estética e seus artigos sobre teoria de diferentes tipos de arte, já no segundo volumes serão publicadas as obras do autor que pertencem ao campo da poética e da história da estética tcheca. [...] (o conteúdo dos volumes por nós preparado foi [apresentado] ao próprio acadêmico Mukařovský, com a esperança de que pudéssemos receber suas observações críticas, as quais não se seguiram). ${ }^{8}$

A julgar pela carta de E. V. Vólkova ${ }^{9}$ a Iu. M. Lótman, de 19 de março de 1971, imaginou-se inicialmente que o parecerista do manuscrito seria M. F. Ovsiánnikov, diretor do comitê editorial da série "História da estética em monumentos literários e documentos", da editora Iskusstvo, para a qual o livro havia sido enviado.

\section{9 de março de 1971}

\section{Prezado Iuri Mikháilovitch!}

Falei hoje com M. F. Ovsiánnikov. Infelizmente ele não recebeu a coletânea de Mukařovský para a elaboração do parecer. Não sei dizer por que a editora não o fez. Tentarei descobrir com M. F. qual é a sua posição. Essas foram suas palavras: "Eu não tenho nenhuma restrição sobre essa edição. Se publicamos Hartmann e Ingarden, ${ }^{10}$ por que não podemos publicar Mukařovský?! Eu inclusive já me manifestei nesse sentido no conselho editorial". Eu encaminhei para ele as informações sobre Mukařovský. A única coisa que não mencionei foi o fato de o senhor considerar que a coletânea "será um acontecimento científico de primeira importância". Ocorre que a pesquisa estruturalista não está no escopo de interesses científicos de M. F., embora ele não suporte toda sorte de improvisações metafóricas defendidas por Paliévs-

\footnotetext{
8 JLSV, f. 1, s.n. Datilografado.

9 Elena Vassílievna Vólkova (1927-2014), doutora em letras (1965) e em filosofia (1978), colaboradora do departamento de estética da Faculdade de Filosofia da Universidade de Moscou, posteriormente professora livre-docente (1980) do mesmo departamento. Sobre maior parte de sua correspondência com lu. M. Lótman e Z. G. Mints no período de 11 de março de 1968 a 23 de maio de 1977, ver TÜR, f. 135, Bv283. A maior parte das cartas é endereçada a Mints; além de questões acadêmicas cotidianas, elas discutem a aprovação por parte da Comissão Superior de Atestamento (VAK) da tese de Mints, um processo que se arrastou por alguns anos e sofreu muita protelação. Zara Grigórievna Mints (1927-1990), esposa de lu. M. Lótman, professora livre-docente da Universidade de Tártu.
}

10 HARTMANN, 1958; INGARDEN, 1962. 
$\mathrm{ki}^{11}$ e K. Escrevo isso caso o senhor venha a precisar conversar com Ovsiánnikov. Imagino (mas não sei ao certo) que ele possa manifestar alguns comentários desfavoráveis sobre o prefácio, embora ele tenha profundo respeito pelo senhor e pelo seu trabalho (já o ouvi dizer isso repetidas vezes). Mas ele é o iniciador de muitas edições (além de ser o editor-chefe) sobre estética contemporânea internacional.

Eu acredito que não há parecerista melhor e mais autorizado para tal coletânea. Deus nos livre que o manuscrito caia nas mãos de M. Lífchits!12 Parece que será necessário influenciar Grigorián de algum modo (ouso dar esse conselho ao senhor), para que o manuscrito seja enviado, conforme a decisão inicial, justamente para Ovsiánnikov.

Se o senhor estiver em Moscou e precisar de mim, telefone em minha residência 266-59-91, acrescentando 6-06. Forte abraço a Zária Grigórievna! ${ }^{13}$

Respeitosamente, E. Vólkova ${ }^{14}$

Mikhail Fedótovitch Ovsiánnikov (1915-1987) foi especialista em história da filosofia e da estética, doutor (livre-docente) em filosofia (1961), fundador do departamento de estética marxista-leninista da Faculdade de Filosofia da Universidade

\footnotetext{
11 Piotr Vassílievitch Paliévski (1932-2019) foi um crítico literário e teórico de orientação conservadora-nacionalista, doutor em letras (1962), pesquisador do Instituto de Literatura Mundial Górki da Academia de Ciências da URSS; em seguida, obteve o título de livre-docente (1982) e foi diretor-adjunto deste mesmo instituto (1977-1994). Sobre suas manifestações anti-estruturalistas (PALIÉVSKI, 1963; PALIÉVSKI, 1966), ver PILSHCHIKOV, POSELIÁGUIN, TRUNIN, 2018, p. 28-30.
}

12 Mikhail Aleksándrovitch Lífchits (1905-1983) foi filósofo, teórico literário e crítico de arte, um dos mais brilhantes representantes da estética marxista. Nos anos 1930 e 1940, foi seguidor de Georg Lukács, com quem colaborou na revista "Literatúrni krítik" [0 crítico literário]. Nos anos 1960, foi um crítico irreconciliável do modernismo e das metodologias não marxistas no estudo das artes e na "teoria literária ocidental", a qual "cai em vários excessos como a moda contemporânea no estruturalismo" (retirado da resposta da M. A. Lífchits ao questionário "Coletânea metodológica" do Instituto de Literatura Mundial Górki, 1967; Lífchits, 1995, p. 106). Foi membro correspondente (1967) e, posteriormente, membro efetivo da Academia de Artes da URSS (1975). Integrou o comitê editorial da série "História da estética em monumentos literários e documentos".

13 Z. G. Mints.

14 JLSV, f. 1, s.n. Manuscrito. 
de Moscou, diretor desse mesmo departamento (1960-1987), decano da Faculdade de Filosofia da Universidade de Moscou (1968-1974), diretor do setor de estética do Instituto de Filosofia da Academia de Ciência da URSS (1963-1987). Quando, em carta a Lótman de 18 de julho de 1969, B. A. Uspiénski ${ }^{15}$ chamou M. F. Ovsiánnikov de "chefe reconhecido da estética soviética", ${ }^{16}$ na resposta (de 28 de julho de 1969), Lótman caracterizou Ovsiánnikov de modo absolutamente positivo:

Embora seja um alto dignatário da filosofia, dizem que Ovsiánnikov é um homem correto, além de um filósofo qualificado, afinal de contas, trata-se de um pupilo de Lukács. Ademais é o patrono das ciências e das artes liberais. ${ }^{17}$

Citado na carta de E. V. Vólkova, V. S. Grigorián ${ }^{18}$ substituiu no posto de diretor da editoria de literatura sobre estética V. G. Kisunkó, que fora removido "por desvios ideológicos" (B. A. Uspiénski a Iu. M. Lótman, 10 de setembro de 1970). ${ }^{19}$ Tudo indica que não foi possível "influenciar Grigorián de algum modo": o parecer sobre a edição de Mukařovský preparada por Lótman e Maliévitch foi fortemente negativo. Ele inclusive serviu de justificativa formal para a recusa da editora em publicar o livro. Os coeditores ficaram sabendo dessa decisão em carta do diretor da Iskusstvo, E. I. Savostiánov, de $1^{\circ}$ de novembro de 1971:

15 Boris Andréievitch Uspiénski (nascido em 1937) é linguista e semiótico de Moscou,
amigo e coautor de lu. M. Lótman.

16 LÓTMAN, USPIÉNSKI, 2016, p. 169.

17 Ibidem, p. 172.

18 Vatche Samviélovitch Grigorián (nascido em 1938) é teórico literário, concluiu doutorado no Instituto de Literatura Mundial Górki. Sobre suas atividades na editora Iskusstvo ver as memórias de BIELÓVA, 2012.

19 LÓTMAN, USPIÉNSKI, 2016, p. 208. Vassíli Grigórievitch Kisunkó (1940-2010) foi teórico e crítico de arte e de cinema. Entre 1967 e 1970, dirigiu a editoria de literatura sobre estética da editora Iskusstvo, tendo sido removido por sua política excessivamente branda em relação a tendências não conformistas do pensamento teórico (inclusive a semiótica de Tártu-Moscou). Após sua saída da editora, dirigiu o departamento de arte da revista Literatúrnoe obozrênie [Revisão literária] (1972-1974), em seguida trabalhou no Instituto Russo de Pesquisa Científica em Estudos sobre Arte. Nos últimos anos de sua vida (1996-2010) foi professor do Conservatório de Moscou. 
Prezados Iuri Mikháilovitch e Oliég Mikháilovitch!

A editoria de literatura sobre estética analisou atentamente a proposta de dois volumes de obras selecionadas de Mukařovský organizada pelos senhores. A opinião da redação coincide inteiramente com a nota do parecerista, que enviamos aos senhores junto com esta carta.

A coletânea apresentada, como evidencia o parecer, foi organizada de forma demasiadamente unilateral, e não apenas não permite julgar a evolução do destacado teórico tcheco do estruturalismo em direção ao marxismo como, ao contrário, revela um Mukařovský inteiramente partidário da orientação formalista nos estudos da literatura e das artes. Por sua vez, o artigo introdutório aos dois volumes, ao invés de apresentar uma análise objetiva, faz uma apologia declarada das visões da semiótica, as quais receberam a ainda recebem críticas fortes e justas em nossa literatura estética. Naturalmente, a editora não pode aprovar e trazer à luz um livro como este, e se vê obrigada a rescindir o contrato no 955/69 de 4 de julho de 1969, fechado com os senhores. ${ }^{20}$

De acordo com O. M. Maliévitch, na carta citada estava escrito a mão: "A cópia do parecer foi enviada ao camarada Lótman" (idem). O nome do parecerista não foi informado aos coeditores.

A reação a essa carta foi a declaração enviada por Lótman e Maliévitch à diretora da Seção Interregional de Leningrado (LMO) da Direção de Proteção aos Direitos Autorais de Toda a União (VUOAP), N. I. Kramarióva. Na declaração, entre outras coisas, a história da proposta é descrita em detalhes:

\section{À diretora da LMO VUOAP Kramarióva Nina Ivanovna}

Lótman Iuri Mikháilovitch

Professor titular,

Doutor (livre-docente) em Letras,

Diretor do departamento de literatura russa da Universida-

de Estatal de Tártu 
Maliévitch Oliég Mikháilovitch,

Doutor em Letras,

Membro da União dos Escritores da URSS

\section{Declaração}

Em 20 de junho de 1969, nós, juntamente com a tradutora de Leningrado V. A. Kamiénskaia, enviamos uma proposta à editoria de literatura sobre estética da editora Iskusstvo (Moscou), à qual propusemos a publicação de uma tradução russa de trabalhos do eminente teórico tcheco, o acadêmico Jan Mukařovský. Com base nessa proposta, em 4 de julho de 1969 a editora Iskusstvo, na pessoa do diretor Savostiánov Evguêni Ivánovitch, fechou conosco, em ato solidário, o contrato no 55/69 incluindo o artigo introdutório (2 laudas), a organização (55 laudas) e os comentários (2 laudas), ao preço de 300 rublos por lauda do artigo, 120 rublos por lauda dos comentários e 40 rublos por lauda pela organização, com data de entrega do prefácio e dos comentários em $1^{\circ}$ de janeiro de 1971. Uma composição detalhadamente comentada dos dois volumes da "Estética" de Jan Mukařovský foi apresentada por O. M. Maliévitch em agosto de 1969 (15 páginas datilografadas). ${ }^{21}$ Ela foi baseada nos conhecidos livros de Mukařovský Estudos estéticos (1966)22 e Capítulos da poética tcheca (segunda edição de 1948). ${ }^{23}$ Com base nessa composição, foi fechado o contrato no $1021 \mathrm{com}$ a tradutora V. A. Kamiénskaia em 21 de agosto de 1969 para a tradução do tcheco da edição em dois volumes de "Estética" de Jan Mukařovský de 55 laudas, com entrega do manuscrito em $1^{\circ}$ de janeiro de 1971 . Nas condições especiais do contrato feito conosco, o "prazo para aprovação e edição seria feito a partir do cálculo do volume da coletânea como um todo". Contudo, uma vez que a composição da coletânea já havia sido apresentada à editora, O. M. Maliévitch enviou ao então diretor da divisão de literatura sobre estética da

\footnotetext{
21 Inacessível. Sobre a descrição da estrutura e composição da edição, ver LÓTMAN, 2018, p. 350-355.
}

22 MUKAŘOVSKÝ, 1966. Na coletânea que marcou o aniversário de 75 anos do teórico estão incluídos seus trabalhos de 1931 a 1948. 0 livro traz um prefácio de Felix Vodička ("O processo criativo nos trabalhos de Mukařovský") e um posfácio de Květoslav Chvatík ("A estética de Jan Mukařovský"). 
editora Iskusstvo, Vassíli Grigórievitch Kisunkó, uma carta perguntando sobre a confirmação da composição da coletânea. V. G. Kisunkó, em carta a O. M. Maliévitch, respondeu que o contrato com a tradutora deveria ser compreendido como a aprovação da composição.

No contrato feito conosco, em violação ao contrato padrão, não foi realizado o pagamento de $25 \%$ dos honorários. 0 . M. Maliévitch não recebeu os $60 \%$ pela organização após a apresentação efetiva da composição em agosto de 1969 e sua aprovação de fato pela editora, expresso no contrato selado sobre a tradução.

Em dezembro de 1970, Iu. M. Lótman apresentou à editora o texto do artigo introdutório. Em janeiro de 1971 (no período de carência), Iu. M. Lótman e O. M. Maliévitch apresentaram à editora o texto dos comentários. Em 4 de fevereiro de 1971, a tradutora enviou à editora, por carta registrada, a tradução de toda a coletânea.

Em $1^{\circ}$ de novembro de 1971, o diretor da editora Iskusstvo, E. I. Savostiánov nos enviou uma carta em que informa sobre o rompimento do contrato.

Consideramos que o rompimento do contrato não tem qualquer base (sobre isso escrevemos em carta à editora) e é juridicamente ilegal, uma vez que não violamos nem uma das cláusulas do ponto 10 do contrato padrão com a editora de 1967 e não nos foi solicitado fazer nehuma alteração na composição, no artigo introdutório ou nos comentários no sentido de sua reelaboração.

Pedimos ao LMO VUOAP que assuma a defesa de nossos interesses e que se manifeste junto à editora Iskusstvo sobre os $25 \%$ de honorários que nos cabem, conforme o contrato no 55/69, uma vez que se trata de um texto artístico literário, mais os $35 \%$ de honorários, uma vez que a editora efetivamente aprovou a composição e não observou as condições de rompimento do contrato.

Apresentamos o contrato editorial no 55/69, o recibo postal com a data do envio do manuscrito completo, a carta da editora endereçada a nós datada de $1^{\circ}$ de novembro de 1969 com a informação sobre a rompimento do contrato, o parecer sobre a composição, comentários e artigo introdutório, com cuja opinião a editora se solidariza, bem como nossa resposta ao diretor da editora E. I. Savostiánov. 
10 de novembro de 1971

Nossos endereços: RSS da Estônia, Tártu, Rua Burdenko, 63, apto 6

Lótman Iuri Mikháilovitch

197061, Leningrado, Rua Divenskaia, 9/3, apto 61

Maliévitch Olieg Mikháilovitch. Telefone 32-71-3524

A resposta a Savostiánov foi escrita ao mesmo tempo em que a declaração citada. A primeira versão, escrita apenas por Lótman, é datada de 12 de novembro de 1971. O parecer da editora que foi o motivo da rejeição da proposta ainda não foi descoberto, contudo, o texto de Lótman dá uma ideia do tipo de afirmações que foram expressas pelo parecerista anônimo e apoiadas pela carta editorial que o acompanhava.

\section{Prezado camarada Savostiánov!}

Tendo recebido sua carta e uma cópia incompleta do parecer ao manuscrito apresentado à sua editora por mim e por O. M. Maliévitch do livro Jan Mukařovský, Investigação sobre teoria da arte, volumes I e II, eu, infelizmente, não posso concordar com as opiniões expressas e, por conseguinte, aceitar o rompimento do nosso contrato como sendo justificado essencial e legalmente do ponto de vista da forma jurídica.

Inicialmente irei me deter no artigo introdutório. ${ }^{25}$ Sobre ele, sua carta diz o seguinte: "o artigo introdutório aos dois volumes, ao invés de apresentar uma análise objetiva, faz uma apologia declarada das visões da semiótica, as quais receberam a ainda recebem críticas fortes e justas em nossa literatura estética". É impossível concordar com isso. Em um dos parágrafos de sua carta, o senhor condena todo um campo científico, uma disciplina, sem a qual seriam impossíveis tanto a cibernética contemporânea quanto a teoria da informação. Isso soa estranho. De fato, é incorreto que a aplicação de princípios da análise semiótica à

24 JLSV, f. 1, s.n. Datilografado.

250 artigo "Jan Mukařovský, teórico da arte" (para sua versão original, ver: LÓTMAN, 2018, p. 356-390; comentários de Igor Pilshchikov: Idem, p. 390-411). 
arte tenha sofrido rejeição unânime na ciência soviética. $O$ acadêmico $\mathrm{M}$. Khráptchenko ${ }^{26}$ concluiu seu longo artigo "A semiótica e a criação artística", publicado nos números 9 e 10 de Vopróssy literatury [Perguntas de literatura], em 1971, com as seguintes palavras: "Embora a resolução de muitos problemas importantes da semiótica da arte ainda estejam colocados, gostaria de ressaltar que o estudo dos fenômenos sígnicos nessa área e sua correlação com diferentes tipos de reflexo da imagem da realidade é fundamental não apenas para uma compreensão profunda acerca da especificidade da arte, da diversidade e contradições de seu desenvolvimento histórico, como também para a elucidação das ligações amplas e dos pontos de contato internos que existem entre a cultura artística e outras formas de atividade criativa humana. Justamente por isso a elaboração positiva dos problemas da semiótica da arte à luz da metodologia marxista-leninista, penso eu, exige uma atenção significativamente maior por parte dos pesquisadores do que a concedida até o momento". ${ }^{27}$

Eu escolhi conscientemente o artigo de um teórico que em uma série de questões se afasta do meu próprio entendimento de arte e o submete à crítica para que fique absolutamente claro que não se pode falar em condenação da semiótica como tal. A condenação da semiótica encontra-se no nível totalmente ultrapassado das afirmações que circulavam nos anos 1950 de que a "cibernética é uma invenção burguesa". Mesmo as pessoas que, naquela época, escreviam artigos longos sobre esse tema tentam hoje os esquecer. Juntamente com o acadêmico Khráptchenko, é possível dizer que a tarefa consiste em desenvolver a semiótica marxista-leninista e não em "condenar as visões semióticas" como tal. Por isso, na condição de autor, eu esperava que meu artigo fosse analisado de forma argumentativa, que a editoria expressasse o desejo de alterar ou indicar precisamente determinada posição ou mesmo submetesse o artigo a uma reelaboração fundamental. Eu obviamente não me recusaria a discutir todas as sugestões construtivas ao artigo, tampouco trabalhar mais, ou mesmo substancialmente, sobre ele. Ao invés de uma crítica construtiva, a editoria tomou outro caminho: ela condenou toda

26 Mikhail Boríssovitch Khráptchenko (1904-1986) foi um acadêmico secretário da Seção de Literatura e Língua da Academia de Siências da URSS de 1966 a 1986. 
uma disciplina científica e rejeitou meu artigo não por suas deficiências, mas pela filiação a determinada orientação científica e pelo uso de certa metodologia científica.

Na mesma posição insiste também o parecerista. Na prática, ele passou ao largo do artigo, limitando-se apenas a alguns exemplos recortados, cujos sentidos ele não compreendeu, ${ }^{28}$ e a alguns epítetos, que demonstram mais o desejo de polemizar do que capacidade de julgar de forma imparcial uma questão científica. A crítica do parecerista foi dirigida contra o estruturalismo como tal, atestando que a filiação a essa orientação científica contradiz o marxismo e constitui fundamento suficiente para que o artigo fosse rejeitado.

Será que a opinião do parecerista foi objetiva? É sabido que dentro das fronteiras dos métodos estruturalistas trabalham tanto teóricos marxistas quanto não marxistas, tanto dentro quanto fora da URSS. Um órgão tão importante quanto a Enciclopédia filosófica enxerga essa questão sem o nervosismo expresso pelo parecerista. Nela encontramos uma avaliação objetiva dessa orientação, indicando a possibilidade de variados tratamentos filosóficos. Em particular, é dito: "Uma tendência científica saudável, que está na base do estruturalismo, é orientada para a aproximação entre as ciências sobre o ser humano e as ciências naturais", ${ }^{29}$ uma passagem que trata daquilo que o parecerista desdenha como sendo "codofilia".

Assim a conclusão da editoria está baseada em um parecer unilateral, que não representa em absoluto a opinião da totalidade da ciência soviética, sendo antes uma tentativa de impor as convicções subjetivas - e ademais absolutamente arcaicas - do parecerista.

Repito que teria interesse em receber quaisquer julgamentos, mesmo que os mais severos, desde que concretos e qualificados sobre meu artigo, e não me recusaria a levá-los em conta. Contudo, considero a posição tomada pela editoria desconstrutiva e infundada.

280 erro do parecerista está ligado aos termos das ciências exatas que o parecerista desconhece, mas que são hoje amplamente aceitos nas disciplinas humanitárias. Neles o parecerista vê apenas um "palavreado da moda" e ele simplesmente não compreendeu o sentido das declarações que estava julgando. 0 atraso na teoria vinga-se. (Nota de lu. M. Lótman).

29 SEGAL, SENOKOSSOV, 1970, p. 145. Ver o parecer da editora de Lótman sobre esse artigo e nosso comentário a ele em LÓTMAN, 2018, p. 306-311. 
O parecerista não realizou uma análise do artigo, afirmando que "esmiuçar passo a passo" o texto seria um "trabalho improdutivo", alegando "falta de espaço" (p. 3). Adiante, ele se recusa a fazer uma análise fundamental dos artigos de $\mathrm{Mu}$ kařovský selecionados para a coletânea, justificando-se que "para isso seriam necessárias muitas páginas" (p. 6). Eu não sei o que faltou ao parecerista, competência ou boa-fé, mas estou firmemente convencido de que tal parecer não pode servir como fundamento jurídico e científico para avaliar o trabalho que foi apresentado. Se à editora foi entregue um manuscrito de mais de 50 laudas e a editora se comprometeu de dar ao autor uma resposta argumentada, a menção do parecerista à falta de espaço e ao desejo de economizar tempo não podem ser levados em conta. A substituição de uma avaliação objetiva e bem argumentada por exemplos recortados (um do artigo introdutório, que tem ao todo 2 laudas, e um do texto do livro, cujo volume é de 50 laudas!), a tentativa de não avaliar efetivamente o trabalho feito, mas colar rótulos nos cientistas e em toda uma orientação científica, nos obriga a supor que, nesse caso, a editora se desviou do cumprimento das obrigações que lhe cabiam.

As objeções feitas à composição dos textos de Mukařovský tampouco podem ser aceitas:

Em primeiro lugar, por motivos jurídicos, a composição foi acordada com a editora e aprovada por ela;

Em segundo lugar, pela essência da questão: o senhor escreve que a seleção dos artigos tem um caráter unilateral que não permite julgar sobre a evolução do estudioso. $\mathrm{Na}$ realidade, esse não é o caso: os artigos revelam integralmente todo o percurso de Mukařovský, a seleção tomou por base as mais recentes e importantes coletâneas e foi acordada com o próprio autor, que considera que justamente tal composição oferece uma ideia objetiva de sua trajetória científica. Não foram incluídos na coletânea os artigos do começo dos anos 1950, que são inteiramente dedicados aos trabalhos de I. V. Stálin sobre questões de linguística e problemas econômicos, ${ }^{30}$ novamente por sugestão do autor. Talvez seja isso que o senhor chama de trabalhos marxistas que deveriam ter sido incluídos e sem os quais a imagem

30 MUKAŘOVSKÝ, 1949a; MUKAŘOVSKÝ, 1949b; MUKAŘOVSKÝ, 1951; MUKAŘOVSKÝ, 1953 Sobre o rompimento de Mukařovský com o estruturalismo e sua virada para o marxismo ver: ČERVENKA, 1991; ZELENKA 2012; KŘíž, 2014, p. 144-148; BEASLEY-MURRAY, 2015; SLÁDEK, 2015, p. 289-348; ŠMAHELOVÁ, 2015; STEINER, 2020. 
de Mukařovský como teórico resulta distorcida? O próprio Mukařovský é de outra opinião, e nós concordamos com ele. Caso se trate de quaisquer outros trabalhos (dos quais nós, infelizmente, não temos conhecimento) - o senhor certamente sabe que nos últimos vinte anos Mukařovský escreveu pouco - nós ficaríamos gratos se o senhor pudesse dar indicações concretas. Nesse caso, seria o caso de alterar a composição da coletânea e não de descartá-la. É essencial ressaltar que tal alteração não exigiria maiores esforços, uma vez que o volume escrito por Mukařovský no último período de sua criação é parco, e se excluirmos os trabalhos mencionados acima, dedicados à obra de I. V. Stálin, uma reformulação essencial da coletânea não seria necessária mesmo se fossem incluídos não apenas os trabalhos recentes mais importantes e interessantes, como nós fizemos, mas todos eles.

Por fim, gostaria de chamar atenção para o fato de que as edições de Mukařovský em países do campo socialista seguem aos mesmos princípios de seleção dos textos que os adotados por nós. ${ }^{31}$

Em conclusão ao que foi dito, sou forçado a observar, com lamento, que a decisão da editora não se mostra fundamentada nem em termos jurídicos nem em sua essência, e eu sou levado a tomar medidas pela defesa de meus direitos autorais.

Respeitosamente,

Doutor (livre-docente) em Letras, professor titular

Iu. Lótman

12 de novembro de $1971^{32}$

Mais detalhes sobre o conteúdo do parecer podem ser encontrados na segunda versão da carta, escrita por Maliévitch a partir do texto de Lótman e essencialmente complementada:33

\footnotetext{
31 Naquela época, as obras de Mukařovský foram publicadas em países socialistas em tradução para o eslovaco (MUKAŘOVSKÝ, 1961) e para o polonês (MUKAŘOVSKÝ, 1970b). Contudo, em termos da composição, a coletânea de Lótman e Maliévitch se revela mais próxima da edição alemã, lançada na Alemanha Ocidental: um volume de trabalhos sobre estética (MUKAŘOVSKÝ, 1970a) e um volume de trabalhos sobre poética (MUKAŘOVSKÝ, 1967)
}

32 JLSV, f. 1, s.n. Datilografado; assinatura manuscrita. 
[...] não podemos de forma alguma concordar com as afirmações contidas em sua carta e no parecer sobre o fato de Mukařovský aparecer na coletânea como defensor da orientação formalista nos estudos literários e da arte, e que a composição proposta não permite avaliar a evolução do teórico em direção ao marxismo.

Mukařovský se afastou do método formal ainda no começo dos anos 1930. No artigo "Sobre a tradução para o tcheco de Teoria da prosa, de Chklóvski" (1934), ${ }^{34}$ Mukařovský escreve: "Nós temos consciência de que a tese 'Tudo na obra é forma' pode e até deve ser contraposta pela antítese 'Tudo na obra é conteúdo', a qual também diz respeito a todos os elementos, e depois disso buscar uma síntese de um e outro, como tenta fazer o estruturalismo contemporâneo..." (Segundo volume do manuscrito, p. 598) ${ }^{35} \mathrm{E}$ adiante: "cada fato literário aparece como resultante de duas forças: a dinâmica interna da estrutura e a interferência externa. O erro da história tradicional da literatura consiste em que ela se atentava à interferência externa e recusava que a literatura tivesse um desenvolvimento autônomo; já a unilateralidade do formalismo consiste em que eles identificaram o processo literário no vácuo" (idem, p. 602) ${ }^{36} \mathrm{Na}$ composição foram incluídos apenas três trabalhos de Mukařovský do começo dos anos 1930 (dois deles dedicados aos problemas da arte cinematográfica, que nada têm a ver com o método formal, ${ }^{37}$ o terceiro trata de Šalda ${ }^{38}$ como precursor do estruturalis-

se lê: "Escrevi a carta para Savostiánov em meu nome pessoalmente, assim eu o entendi. Se for necessária uma carta conjunta, reescreva substituindo "eu" por "nós" [...] Ou então funda nossos projetos, ou ainda mande duas cartas: de minha e de sua parte" (JLSV, f. 4.4, s.n. A primeira metade da página está datilografada, a segunda, manuscrita).

34 Esse artigo foi publicado pouco depois na coletânea "Estruturalismo: a favor e contra", com tradução de V. A. Kamiénskaia (MUKAŘOVSKÝ, 1975 [1934]).

35 Ver MUKAŘOVSKÝ, 1975 [1934], p. 30; MUKAŘOVSKÝ, 1996, p. 416.

36 Ver MUKAŘOVSKÝ, 1975 [1934], p. 33; MUKAŘOVSKÝ, 1996, p. 418.

37 "Sobre a questão da estética do cinema" e "O tempo no cinema" (MUKAŘOVSKÝ, 1994, p. 396-410, 410-319).

38 "F. X. Šalda e a teoria da literatura" (MUKAŘOVSKÝ, 1996, p. 406-412). František Xaver Šalda (1867-1937) foi o fundador da crítica literária tcheca contemporânea, autor dos livros "Boje o zítřek" [Batalha pelo amanhã, 1905), "Duše a dílo” [Alma e criação, 1913], "0 nejmladší poezii české" [Sobre a mais jovem poesia tcheca, 1928), entre outros. A ele são dedicados três artigos de Mukařovský, sendo que um deles entrou na edição russa e os outros dois, que na edição tcheca de 1948 foram reunidos sob o título "Dois estudos sobre Šalda" (MUKAŘOVSKÝ, 1948, t. I, p. 303-336), não foram incluídos na edição ("F. X. Šalda", 1937, "F. X. Šalda, crítico da vida popular, 1947). 
mo). ${ }^{39} \mathrm{O}$ trabalho que abre a edição, "Função, norma e valor estético como fatos sociais" (1936), anuncia no próprio nome a orientação do autor para um entendimento social do problema da estética. ${ }^{40}$ Já em 1934, a crítica marxista tcheca (Kurt Konrad) observou que Mukařovský deu um passo em direção ao "estudo materialista-dialético da literatura" (K. Konrad, Ztvárněte skutečnost, Praha, 1963, p. 88). Já em relação à obra mais recente de Mukařovský essa crítica na pessoa de Bedřich Václavek escreveu com aprovação que, em sua compreensão, a "função estética é uma das muitas funções autônomas do organismo social multifuncional", que se influenciam entre si, e que ele evita tanto o formalismo extremo, que isola a obra de arte, quanto o sociologismo extremo, que "não considera a autonomia interna"41 da arte. "O que é a função estética, qual função é precisamente estética?", pergunta o parecerista, aparentemente sem notar que Mukařovský analisa a função estética como uma síntese particular de funções não estéticas que afetam não apenas a razão, mas também as emoções humanas. Diferentemente do parecerista, que demonstra ser adepto de uma noção que parte do idealismo objetivo, segundo a qual o estético é uma propriedade real das coisas, assim como suas propriedades físicas, Mukařovský considera que "a estabilizacao da função estética é um feito coletivo, e a função estética aparece como um elemento de relação entre o coletivo humano e o mundo". ${ }^{42} \mathrm{~A}$ base objetiva do valor estético é a capacidade potencial do artefato material de tornar-se um objeto estético da consciência social. [...] Aquilo que escreve o parecerista nas páginas 7 a 10, obriga-nos a pensar que ele simplesmente não leu Mukařovský ou o leu sem a devida atenção. Ele deixa escapar algumas teses de Mukařovský, como a afirmação de que as leis da

39 Dentre obras teóricas mais importantes de Mukařovský do começo dos anos 1930 não foram incluídos na edição russa os artigos "Linguagem literária e linguagem poética" (MUKAŘOVSKÝ, 1932), publicado em russo com tradução de Aleksandra Grigórievna Chirókova (1918-2003) na coletânea "O círculo linguístico de Praga" (MUKAŘOVSKÝ, 1967 [1932]).

40 Esse artigo foi publicado pouco depois no sétimo volume dos "Trabalhos sobre sistemas sígnicos" (MUKAŘOVSKÝ, 1975 [1936]), com uma nota preliminar de lu. M. Lótman (LÓTMAN, 1975). Todo o volume é dedicado à memória de Piotr Grigórievitch Bogatyrióv (18931971), fundador da teoria semiótica do folclore e dos estudos teatrais semióticos, além de ter sido um dos participantes mais ativos do Círculo Linguístico de Praga.

41 VÁCLAVEK, B. Literární studie a podobizny. Praha, 1962, p. 223.

42 Do artigo "Função, norma e valor estético como fatos sociais" (ver MUKAŘOVSKÝ, 1975 [1936], p. 253; MUKAŘOVSKÝ, 1994, p. 53). 
arte são a base objetiva na qual ocorre a evolução da norma estética; ou a diferenciação entre função sígnica simbólica e função sígnica estética, que faz avançar para o primeiro plano o sujeito, pois, para ele, na obra de arte, nesse signo que reflete o universo da existência, se concentra toda a realidade etc. Mukařovský não ignora em absoluto o problema da criação (artigo "O premeditado e o não premeditado na arte") ${ }^{43}$ nem o problema da personalidade criadora (uma série de artigos). ${ }^{44}$ Ademais o uso de princípios da semiótica, o estudo das funções, da linguística contemporânea não o impede de basear-se, sem cair absolutamente em ecletismo, em obras de clássicos da estética, especialmente Hegel (ver artigo "Sobre a metodologia do estudo da literatura"). ${ }^{45}$ Sobre sua evolução ulterior, o próprio Mukařovský escreveu em prefácio à segunda edição de "Capítulos da poética tcheca" (publicado pela primeira vez em 1940): "No que se refere à evolução científica do autor, observada no prefácio à primeira edição, é preciso mencionar de passagem um novo traço, que se manifestava de forma bastante clara já no momento da primeira edição, embora naquela época (no período da ocupação) não fosse possível falar dele abertamente, e o qual desde então passou a ser a força motriz de todo desenvolvimento ulterior do autor: sua aproximação com o materialismo dialético. Contudo trata-se não da chamada "aplicação" do marxismo à arte, mas de uma conclusão lógica do próprio desenvolvimento científico do autor. A ponte para essa aproximação foram, antes de tudo, a dialética e o materialismo gnosiológico, ou seja, a visão segundo a qual o objeto de conhecimento é uma realidade material; o sujeito cognoscente é ele mesmo parte integral dessa realidade e, dessa forma, ela determina todas as relações que o objeto cognoscente pode ter com ela". ${ }^{46} \mathrm{O}$ parecerista tenta apresentar a questão como se Mukařovský tivesse abandonado todo o sistema de ideias expresso nas obras da segunda metade dos anos 1930 e nos anos 1940, que estão incluídas na edição em dois volumes (ele o faz passar

\footnotetext{
43 Ver MUKAŘOVSKÝ, 1994, p. 198-244.

44 Ver, por exemplo, "O indivíduo na arte", "A personalidade na arte", "Experiência de análise estrutural da individualidade do ator", "O indivíduo e o desenvolvimento literário", entre outros (MUKAŘOVSKÝ, 1994, p. 496-501, 501-521, 420-427; MUKAŘOVSKÝ, 1996, p. 378-394)
}

45 Ver MUKAŘOVSKÝ, 1996, p. 421-437.

46 MUKAŘOVSKÝ, 1948, t. I, p. 12 
por um formalista e um eclético, substituindo as visões do próprio Mukařovský por visões que ele rechaça, cf. p. 1-2 do parecer). Na realidade, segundo a nossa perspectiva, esse não é o caso. No "Apêndice do autor" (de junho de 1966) ao livro Estudos estéticos, Mukařovský escreve: "[...] o livro é resultado de um esforço determinado a cada etapa por uma orientação gnoseológica única. Contudo, justamente por se tratar de um processo cognitivo, da colocação de questões que não eram colocadas no estudo da arte no momento da emergência dos artigos isoladamente, não é um caminho univocamente reto... Se alguém desenha para si o caminho de um processo cognitivo na forma de uma estrada reta e plana, essa pessoa não tem a menor ideia acerca da essência e das condições do pensamento científico. Assim o caminho não foi predeterminado de antemão, existiam apenas as insistentes e inevitáveis questões que surgiram gradualmente, e a convicção do autor de que o método dialético de pensamento abre caminho para a estética marxista. O autor tentou, por meio do método dialético, levar até o fim a resolução de algumas questões fundamentais da estética, o que pode ser verificado, por exemplo, nos artigos já mencionados sobre o premeditado e o não premeditado ou sobre o indivíduo na arte. Exatamente da mesma forma, os problemas do signo e do significado eram, para o autor, problemas da relação dialética entre arte e realidade e entre arte e sujeito. Nisso ele enxerga a justificativa para o lançamento do livro para si e, provavelmente, também para os esforços da estética contemporânea" (idem, p. 337). ${ }^{47}$ Nos artigos "Sobre a terminologia da teoria tchecoslovaca da arte" (1947), "Arte e visão de mundo" (1947), "Sobre a questão do estilo individual na literatura" (1958) (todos foram incluídos na edição em dois volumes) ${ }_{{ }^{48}}$ Mukařovský fala abertamente sobre a relação de suas visões com o marxismo, com o materialismo histórico e dialético (neste último ele indica com precisão algumas de suas teses iniciais justamente a partir de uma posição marxista). ${ }^{49}$

47 MUKAŘOVSKÝ, 1966, p. 337.

48 Cf. MUKAŘOVSKÝ, 1994, p. 291-307, 525-540; MUKAŘOVSKÝ, 1996, p. 356-377.

49 Mais tarde os coeditores caracterizaram o artigo "Sobre a questão do estilo individual na literatura", de Mukařovský, uma palestra do autor no IV Congresso Internacional de Eslavistas (Moscou, 1958), como um texto no qual "se manifesta uma tendência à sociologização estreita, característica dos estudos literários tchecos dos anos 1950 e início dos anos 1960" (MUKAŘOVSKÝ, 1996, p. 471). 
É preciso dizer que, de modo geral, as avaliações de $\mathrm{Mu}-$ kařovský na carta e no parecer são bastante contraditórias: ora tratam-no como se fosse um formalista e um eclético, ora "as obras reunidas neste livro são fruto de toda a vida de uma pessoa indubitavelmente educada, espiritualmente honesta, interessada em uma análise profunda, e não superficial, da esfera que a estética 'dirige'”' (p. 2). 0 parecerista encontra "algo útil em suas pesquisas (que são pouco publicados em nosso país) e para o leitor soviético" (idem) e diz até que "em outras condições" "seria a favor da publicação da coletânea de obras do acadêmico tcheco" (p. 10). Em que sentido o momento atual não é apropriado e quais "condições" é preciso esperar para a edição das obras de Mukařovský? Partindo do conteúdo geral do parecer, é possível concluir que esse momento chegará quando cessarem todas as tentativas de estabelecer um contato entre as ciências exatas e humanas (em particular a estética) e o pensamento dos teóricos regredir inteiramente a Platão, Aristóteles etc., que são tão caros ao parecista. Nós compreendemos o marxismo criativo de forma um pouco diferente, lembrando a ideia de Lênin de que o cientista marxista deve considerar e compreender todas as últimas conquistas da ciência a partir da posição do materialismo dialético. ${ }^{50}$

No momento em que as obras de J. Mukařovský se tornam para nós cada vez mais um objeto de polêmica científica, seria natural não evitar sua edição, mas publicar em um volume tal que dê uma ideia bastante completa sobre o sistema de visões do eminente teórico e sua evolução. Ao que parece, a editora baseou-se justamente nesse ponto de vista ao fechar o contrato conosco em uma declaração na qual se diz abertamente: "O valor das obras de Mukařovský sobre estética, teoria da arte e poética reside, em primeiro lugar, na aplicação criativa da dialética e, em seus trabalhos mais maduros, da dialética materialista aos problemas específicos de tais ciências. No momento presente, em que a semiótica e os métodos matemáticos de pesquisa no campo das ciências humanas se desenvolvem sobre bases marxistas, as obras de Mukařovský dedicadas à base sígnica da arte, da literatura e da linguagem poética adquirem um

50 Ver VI. Ilin [Vladímir Uliánov-Lênin], Materializm e empiriokrititsizm [Materialismo e empiriocriticismo] (1908), capítulo V ("Novéichaia revoliútsiia v estestvoznánii i filossófski idealizm" ["A novíssima revolução das ciências naturais e o idealismo filosófico]). 
significado especial". Agora a editora mudou de opinião. Justamente por esse mesmo motivo ela rejeita a edição, recusando quaisquer tentativas de resolver a questão de forma produtiva e positiva. Dessa forma, não se trata absolutamente de que o manuscrito entregue por nós seja de má qualidade (nem a editora nem o parecerista fizeram esse tipo alegação sobre as duas laudas de comentários). Mas a questão da utilidade ou inutilidade da edição de obras de Mukařovský deveria obrigatoriamente ter sido resolvida antes de se fechar o contrato, e nós não temos nenhuma responsabilidade pela mudança de planos da editora. ${ }^{51}$

Para fortalecer a argumentação, além da citação ritualística ao artigo de Khráptchenko sobre a semiótica marxista, foi incluído um exame sobre a polêmica acerca dos métodos semióticos no estudo da literatura que compõe uma detalhada nota de uma página e meia:52

Nos anos 1970 e 1971, a revista Novy mir [Novo Mundo] publicou um ciclo de artigos sob o título geral de "Ciência da literatura hoje". Estas são algumas declarações de diferentes autores sobre a vertente dos estudos literários à qual pertence Iu. M. Lótman: "Um fenômeno notável são também os Trabalhos sobre sistemas sígnicos, volume quatro (a orientação de jovens pesquisadores liderados por Iu. Lótman), embora eles despertem controvérsias no meio científico"53, "[...] os trabalhos de teoria literária dos últimos anos - Konrad, ${ }^{54}$ Likhatchóv, Lótman e sua escola - a

51 JLSV, f. 1, s.n. Datilografado, fol. 7-12.

52 Na mesma declaração anexa, Lótman aconselhou: "Depois de pensar, decidi que em todo caso é preciso fazer referência a Konrad, Bakhtin e Andrónnikov na Novy mir" (JLSV, f. 4.4, s.n.). Sobre as relações entre Bakhtin e a Escola Tártu-Moscou, ver: IVÁNOV, 1973b; TITUNIK, 1976; TITUNIK, 1981; DANOW, 1988; REID, 1990a; REID, 1990b; REID, 1991; SHUKMAN, 1989; GRZYBEK, 1995; BETHEA, 1997; EGOROV, 1999: 243-258; KASSAVIN, 2007; SZCZUKIN, 2008; AVTONÓMOVA, 2009: 184-202; e muitos outros. 0 primeiro dos artigos referidos foi publicado no IV volume dos "Trabalhos sobre sistemas sígnicos", que saiu com o subtítulo "Coletânea de artigos científicos em homenagem a Mikhail Mikháilovitch Bakhtin (pelo seu $75^{\circ}$ aniversário)".

53 M. Bakhtin, "Aproveitar as oportunidades com mais ousadia", Novy mir, 1970, no 11, p. 237.

54 Nikolai lóssifovitch Konrad (1891-1970) foi um clássico dos estudos orientais russos, acadêmico da Academia de Ciências da URSS (1958). A semiótica de Moscou e de Tártu tinha seus trabalhos sobre as tipologias da cultura em alta conta (ver IVÁNOV, 1973a). 
despeito das diferenças metodológicas, se igualam ao não separar a literatura da cultura, buscando compreender os fenômenos literários em uma unidade diferenciada de toda cultura". ${ }^{55}$ "Nos últimos anos, na teoria literária, observam-se novas tendências. A atenção de alguns pesquisadores se voltou para ao próprio material da obra, isto é, a linguagem. [...] nesse mesmo campo surgiu a abordagem estrutural à linguagem: ela levou a uma busca por construir uma teoria do discurso poético, ou seja, da linguagem específica da literatura artística, em uma base estrutural. Nos casos em que a investigação da língua da literatura se une ao estudo do próprio processo criativo e às esferas da psicologia e da ideologia que o condicionam, a teoria literária se aproxima das fronteiras da semiótica"56; "A matematização da ciência da literatura não significa absolutamente um retorno ao formalismo"57; I. Andrónnikov cita Iu. M. Lótman e seu grupo na lista de nomes e obras que "refletem a condição elevada da ciência literária soviética" (I. Andrónniko$\mathrm{V}^{58}$ "O leitor e 160 milhões", Novi mir, 1971, no 6, p. 228); "A verdade é concreta e me parece que nós devemos arregaçar as mangas e trabalhar sobre os problemas mais urgentes acerca da metodologia da ciência literária, entre os quais, aliás, os problemas do estruturalismo e da semiótica devem ocupar um lugar correspondente ao seu significado real"59. Os métodos semióticos de investigação da arte são apoiados nas páginas da revista Vopróssy filossófii [Perguntas de filosofia] por M. G. Sokolianski ("O estruturalismo na teoria literária”, Vopróssy filossófii, 1969, no 7, p. 112-119: "a orientação da 'Escola de Tártu'[...] tem capacidade para desenvolver e enriquecer a metodologia de nossa teoria literária, a qual não pode existir como algo fossilizado, como um dado eterno", p. 119), U. I. Rijinachvili ("O lugar e o papel das abordagens semióticas no estudo da literatura artística", Vopróssy filossófii, 1971, no 8, p. 136-139: "Pode-se comprovar que justamente com o auxílio dos métodos semióticos

55 lbid, p. 238.

56 Acadêmico N. Konrad, Outubro e as ciências filológicas, Novy mir, 1971, no 1, p. 218.

57 PERTSOV, V. "Axiomas e o desconhecido", Novy mir, 1971, no 4, p. 208.

58 Na publicação citada, bem como na maioria das outras, "Andrónikov". Irakli Luarsábovitch Andrón(n)ikov (Andronikachvili, 1908-1990) foi um estudioso de Lérmontov, escritor e apresentador de televisão, mestre em estudos de histórias orais.

59 Opinião de um dos críticos do estruturalismo, lu. Barabách: "Quo vadis?", Novy mir, 1971, no 12, p. 225. 
é possível elucidar a estreiteza e limitação dos métodos puramente formais, sintáticos", p. 139) entre outros. ${ }^{60}$

Além disso, na mesma carta, a concepção da edição é apresentada em detalhe:

As objeções à composição tampouco podem ser aceitas. O senhor escreve que a seleção de artigos tem um caráter unilateral e não permite julgar sobre a evolução do teórico. $\mathrm{Na}$ realidade isso não procede: os artigos apresentam todo o percurso de Mukařovský. A seleção foi feita com base em coletâneas recentes e prestigosas e tem a concordância do próprio autor e de seus alunos próximos, os quais consideram que justamente essa composição oferece uma ideia objetiva sobre o percurso teórico do acadêmico tcheco. ${ }^{61} \mathrm{~A}$ base no primeiro volume é o livro Estudos estéticos (1966), a mais completa edição dos trabalhos de Jan Mukařovský sobre estética. Nesta obra, os trablahos de Jan Mukařovský foram reunidos pela primeira vez, muitos de seus textos iniciais nunca tinham sido publicados. Foram incluídos todos os artigos das duas primeiras seções - "Estética geral" e "Teoria da arte" (parte dos artigos da segunda seção foram incluídos no segundo volume por considerações de composição). ${ }^{62}$ Da terceira seção, "Sobre a arte e os artistas", foram incluídos todos os artigos teóricos gerais. ${ }^{63}$ Dos 42 artigos que compõem o livro, apenas oito não foram incluídos: "O detalhe como unidade semântica fundamental na arte popular" (devido à dificuldade de tradução dos exemplos ilustrativos) ${ }^{64}$ e sete artigos de caráter particular ou

60 JLSV, f. 1, s.n. Datilografado, fol. 2-2a.

61 Da discussão da composição da edição participaram os alunos de Mukařovský Mojmír Grygar (nascido em 1928) e Miroslav Kačer (1927-1978) (ver MALIÉVITCH, 2009). Na avaliação de Kačer sobre o plano da edição russa, citado pelos organizadores na proposta, lê-se: "É possivel afirmar com todo fundamento que esta edição tão representativa e bem elaborada das obras de Mukařovský é necessária inclusive para nós" (JLSV, f. 1, s.n.; ver KAČER, 1971, p. 81).

62 É preciso levar em conta que a comparação das edições MUKAŘOVSKÝ, 1966, e MUKAŘOVSKÝ, 1948, não é absoluta: na segunda seção da edição de 1966 foram republicados alguns artigos do primeiro volume da edição de 1948.

63 Na edição de Lótman e Maliévitch, eles foram transferidos para o segundo volume. p. 209-222). 
de história literária (sobre um dos livros de Nezval, sobre Vančura, Šíma, Šalda, Toyen, Štyrský, sobre o teatro D34). ${ }^{65}$ Adicionalmente, foram incluídos os textos estéticos de Mukařovský presentes na enciclopédia tcheca ${ }^{66} \mathrm{e} o$ artigo "Principios fundamentais da vanguarda", de 1965. Em nossa composição não foram incluídos textos do final dos anos 1940 e começo dos anos 1950, os quais contém referências a I. V. Stálin e seus trabalhos sobre questões de linguística e problemas econômicos. ${ }^{67}$ Talvez o senhor chame isso de trabalhos marxistas que deveriam ser incluídos e sem os quais a imagem de Mukařovský como teórico resulta distorcida? Caso se trate de outros trabalhos (os quais infelizmente desconhecemos) - o senhor certamente sabe que nos últimos vinte anos Mukařovský pouco tem tratado de questões de estética - nós agradeceríamos se o senhor puder fazer sugestões construtivas. No segundo volume foram incluídos os artigos supracitados do livro Estudos estéticos,

65 "Dois estudos sobre Vítězslav Nezval ("Dvě studie o Vítězslavu Nezvalovi”, 1934, 1938), "Dois estudos sobre Vladislav Vančura ("Dvě studie o Vladislavu Vančurovi", 1934, 1941), "Josef Šíma" (1936), "F. X. Šalda"(1937), "Toyen durante a época da guerra” ("Toyen za války", 1946), "Jindřich Štyrský” (1946), "D34-D48 no desenvolvimento do teatro tcheco" ("D34-D48 ve vývoji českého divadla", 1948). Ver MUKAŘOVSKÝ, 1966, p. 269-285, 286-295, 304-308, 333-336, 312-314, 315-317, 325-327.

Vítězslav Nezval (1900-1958) foi o principal poeta da vanguarda tcheca (e posteriormente 0 fundador do surrealismo tcheco), Vladislav Vančura (1891-1942) foi autor de prosa; ambos foram membros do grupo artístico de "poetistas" Devětsil [Nove-Forças], que existiu entre 1920 e 1930 (o líder do gurpo era o crítico Karel Teige, e o representante mais famoso, 0 poeta Jaroslav Seifert, foi laureado com o prêmio Nobel de literatura em 1984). Josef Šíma (1891-1971) é artista franco-tcheco (ligado ao surrealismo e, posteriormente, à arte abstrata), membro do Devětsil.

Sobre Šalda ver nota 37.

Toyen (cujo nome verdadeiro era Marie Čermínová, 1902-1980) foi artista franco-tcheca, "poetista" e surrealista (aliás ela própria preferia evitar a terminação do gênero feminino). Jindřich Štyrský (1899-1942) foi artista e fotografo surrealista tcheco, membro do Devětsil, em 1934 entrou no Gurpo Surrealista Tcheco ao lado dos organizadores Nezval, Teige e Toyen.

D34 (D, do tcheco divadlo, isso é, teatro), foi um teatro de vanguarda político fundado em 1933 por Emil František Burian. A data em seu nome eram alterados anualmente conforme o ano de encerramento da temporada teatral. D41 foi fechado pelas forças de ocupação alemãs; foi reaberto por três temporadas entre 1946 e 1948.

66 Como foi mencionado na avaliação de Káčer (ver nota 54) "na edição soviética foram incluídos artigos importantes, que Mukařovský escreveu para o "Dicionário científico de Otto para a nova época" (por exemplo, "O belo", "O cômico", "Poética”, "Eufonia”, "Lírica”), os quais, exceto pela enciclopédia, até hoje não foram publicados em tcheco" (ver KAČER, 1971, p. 81; OTTU゚V SLOVNÍK NAUČNÝ 1930-1943, vol. III.2, p. 825; vol. III.1, p. 661; vol. IV.2, p. 118; vol. II.1, s. 471; vol. III.2, p. 1333-1334).

67 Ver nota 29. 
todos os artigos mais importantes sobre estética e poética da literatura do primeiro volume (Problemas gerais da poética) dos Capítulos da poética tcheca (segunda edição de 1948), ${ }^{68}$ os artigos mais importantes em termos teóricos do segundo volume dessa edição, "Princípios gerais do desenvolvimento do verso tcheco do Novo tempo" e "Estrutura semântica e base de composição da épica de Karel Čapek" ${ }^{69}$ Além dos artigos enciclopédicos sobre poética, incluímos o artigo "Sobre a questão da metodologia da teoria literária", publicado pela primeira vez em 1968, e o artigo "Sobre a questão do estilo individual na literatura", de 1958. Nós não incluímos propositalmente na coletânea artigos de caráter polêmico e histórico literário, por supormos que eles não correspondem ao perfil da editoria. ${ }^{70}$

Em resposta, Lótman e Maliévitch receberam uma carta oficial, assinada pelo diretor interino da editoria, V. I. Stúpin:71 COMITÊ DE PUBLICAÇÃO JUNTO AO CONSELHO DE MINISTROS DA URSS

EDITORA ISKUSSTVO

Moscou, I-28, Bulevar Tsvetnói, 25, telefone K 4-07-75

No 43

6 de dezembro de 1971

Aos camaradas Lótman Iu. M. e Maliévitch O. M.

Prezados Iuri Mikháilovitch e Olieg Mikháilovitch!

\footnotetext{
68 Dos vinte artigos que compõem o primeiro volume de Capítulos da poética tcheca, Lótman e Maliévitch selecionaram nove para tradução e publicação: "A obra poética como complexo de valores", "Sobre a terminologia da teoria da arte tchecoslovaca", "Dois estudos sobre a denominação poética"(esses três artigos foram incluídos também em MUKAŘOVSKÝ, 1966), "O estruturalismo na estética e na ciência da literatura", "Estética da linguagem", "Sobre a linguagem poética", "Tradição do surgimento de novas formas", "Resultados e perspectivas" e "Sobre a tradução para o tcheco de 'Teoria da prosa', de Chklóvski".

69 Ver MUKAŘOVSKÝ, 1996, p. 149-250, 325-355.

70 JLSV, f. 1, s.n. Datilografado, f. 5-6.

71 Vladímir Ivánovitch Stúpin (1918-depois de 2000) foi arquiteto, diretor da redação de história e teoria da arquitetura da Stroiizdat. Entre 1971 e 1973 foi editor chefe da Iskusstvo, onde atuou por um período como diretor.
} 
A resposta dos senhores à nossa carta de $1^{\circ}$ de novembro de 1971 não é convincente pelos seguintes motivos:

1) Os senhores não responderam à análise crítica bastante detalhada oferecida pelo parecer que lhes foi enviado, e não abordam em sua resposta nenhuma das questões que ele coloca. Os senhores classificam tudo como "polêmica". Trata-se, contudo, justamente do fato de que o trabalho realizado pelos senhores não atende às exigências apresentadas pelo ponto de vista da teoria pela qual a editora deve orientar-se.

2) Os senhores afirmam que a edição em dois volumes apresentada à editora com trabalhos do estruturalista tcheco Jan Mukařovský reflete toda uma orientação científica, isso é, a semiótica marxista-leninista e, para comprovar seu direito de existir, os senhores citam as opiniões de M. Khráptchenko, M. Bakhtin e outros. Não estamos negando o direto de que a orientação dos senhores exista, e deixamos de lado a questão geral da sua relação com o marxismo-leninismo. Como os senhores sabem, a editora Iskusstvo já lhes garantiu suficientemente a realização de seu direito civil com a edição recente dos livros de Iu. Lótman e B. Uspiénski. ${ }^{72}$ Quanto ao conteúdo do novo trabalho que representa sua orientação, a editora, por sua vez, não apenas tem o direito como é diretamente obrigada a avaliar sua utilidade ideológica, a partir do conteúdo da questão. Nenhuma figura de autoridade que os senhores citam podem nos livrar de tal responsabilidade.

3) Não há fundamento para os senhores acusarem a editora de ser "atrasada" e não ter uma abordagem criativa. Ao propor como bandeira de sua orientação científica as ideias de um idealista e pensador religioso como P. Floriênski (ver Trabalhos sobre sistemas sígnicos, v. III), ${ }^{73}$ os senhores mostraram claramente o que significa uma abordagem criativa nessa perspectiva. Nós não consideramos que a visão de mundo materialista e o princípio realista na estética sejam "atrasados".

4) $\mathrm{O}$ fato de que a coletânea de trabalhos de $\mathrm{Mu}$ kařovský é composta fundamentalmente de obras do

72 LÓTMAN, 1970; USPIÉNSKI, 1970. Ver traduções para o português: LÓTMAN, 1977; USPIÉNSKI, 1981.

73 Ver FLORIÉNSKI, 1967 [1922]. Para uma discussão detalhada dessa obra que antecipa as investigações semióticas dos anos 1960 ver LÓTMAN, USPIÉNSKI, 2016, p. 46-48, 54-58. 
período pré-marxista está indicado no próprio prefácio ao livro. A editora Iskusstvo não se recusaria a publicar alguns trabalhos de Jan Mukařovský em uma coletânea mais ampla, dedicada à estética tchecoslovaca, mas a publicação dessa edição em dois volumes não é considerada útil.

5) Quanto ao aspecto jurídico da questão, a menção ao fato de que a editora conhecia a posição dos organizadores e o programa da edição não tem base. Em sua proposta, os autores se comprometeram a preparar para publicação um livro que apresentasse a pesquisa semiótica da arte em uma base marxista. Em particular, o valor dos trabalhos de Mukařovský é claramente fundamentado na proposta pelo fato de eles serem "aplicações criativas da dialética e, nas obras mais maduras, da dialética materialista". Infelizmente, após a apresentação do manuscrito ficou claro que essa proposta levou a editora ao erro. A edição em dois volumes organizada pelos senhores não cumpre a orientação ideológica prometida e, portanto, não pode ser aceita para publicação.

Diretor interino

$<$ assinatura $>$

(V. Stúpin)

A carta de Stúpin não ficou sem resposta:

Prezado camarada Stúpin!

Sua resposta à nossa carta de $1^{\circ}$ de novembro não nos satisfez pelos seguintes motivos:

1) Como já dissemos, o parecer ao artigo introdutório não apresenta uma análise concreta. Na carta da editora de $1^{\circ}$ de novembro de 1971, não há sugestões de reelaboração. Em tais condições, a conversa sobre o artigo introdutório não tem fundamento.

2) A principal objeção contida na carta e no parecer se resume à acusação de que o autor do prefácio faz apologia das visões semióticas. Agora a editora nega rejeitar por completo essa orientação e até considera que lhe seria de- 
sejável justamente um "livro que apresentasse a pesquisa semiótica da arte em uma base marxista". Nem a carta da editora nem o parecer apresentam objeções a que o artigo introdutório não contenha visões marxistas.

3) Os autores podem ter responsabilidade coletiva apenas pelo trabalho apresentado à editora. Assim, menções a obras pulicadas nos Trabalhos sobre sistemas sígnicos não têm nenhuma relação com a questão que nos interessa aqui. Apenas de passagem é possível responder que Platão, Hegel etc. foram idealistas e Tolstói e Dostoiévski foram pensadores religiosos, o que não os impediu de formular julgamentos estéticos profundos.

4) Os autores da proposta nunca assumiram a obrigação de apresentar apenas as obras marxistas de Jan Mukařovský. Os senhores mesmos citam nossas palavras: "aplicações criativas da dialética e, nos trabalhos mais maduros, da dialética materialista". Segue-se que consideramos marxistas apenas as obras "mais maduras" de Mukařovský. A partir da proposta e da composição, é possível concluir tratar-se de obras da segunda metade dos anos 1940 e posteriores. Reiteramos que o número de tais obras pode ser ampliado. A objeção que a "proposta levou a editora ao erro" é absolutamente infundada.

5) Consideramos que a edição em dois volumes de $\mathrm{Mu}$ kařovský tem grande interesse no momento atual para o leitor soviético e que a orientação geral de seus trabalhos corresponde ao interesse da estética e da teoria da arte marxistas. Na edição em cinco volumes de História da estética, lançada por esta editora, foram incluídos trabalhos de predecessores de Mukařovský, Hostinský, ${ }^{74}$ Šalda, mas não dele mesmo. A editora lançou livros de Nejedlý, Fučík e Čapek. ${ }^{75}$ Evidentemente seria possível editar trabalhos mais completos de Hostinský, Šalda, B. Václavek, Kurt Konrad, L. Štoll etc. ${ }^{76}$ É interessantee também a ideia de

74 OVSIÁNNIKOV, 1968, p. 397-403. Otakar Hostinský (1847-1910) foi um esteta tcheco, teórico da música e crítico musical, adepto do formalismo de Herbart, um empiro-indutivista consequente. Acerca de sua influência sobre o estruturalismo de Praga, ver STEINER, 1982, p. 187 e seguintes.

75 A editora Iskusstvo publicou: "Artigos sobre arte", de Zdeněk Nejedlý, um discípulo e sistematizador das ideias de Hostinský (1960), "Sobre o teatro e a literatura", de Julius Fučík (1964) e "Sobre a arte: Teatro e cinema. Artes plásticas e aplicadas, arquitetura. Literatura", de Karel Čapek (1969). As duas últimas publicações foram editadas por O. M. Maliévitch. 
uma coletânea dedicada à estética tcheca. Contudo parece-nos que os trabalhos de Mukařovský têm hoje um maior valor científico real. A editora tem o direto de não concordar conosco. Mas não tem o direto de rejeitar um trabalho preparado honestamente, privando-nos até da possibilidade de considerar uma crítica positiva, apenas porque agora não considera útil aquilo que considerava no momento da assinatura do contrato e da aprovação efetiva do conteúdo.

19. 12. 1971.

(Iu. M. Lótman)

(O. M. Maliévitch)

Os coautores tentaram resistir, embora reconhecessem a inutilidade de suas tentativas. Na carta enviada nos últimos dias de 1971, Lótman informou Maliévtich:

Encontrei-me com o consultor jurídico do Comitê sobre a defesa dos direitos autorais, e ele se encarregará da questão. Ele considera que devemos cessar quaisquer contatos com a editora, por isso aconselho que você encerre a polêmica epistolar com a Iskusstvo, ela é absolutamente inútil. ${ }^{77}$

\footnotetext{
1981), vice-presidente da Academia de Ciências Tchecoslovaca, representante da teoria stalinista-jdanovista da arte, crítico implacável do estruturalismo tcheco e do formalismo russo, "the Party watchdog for ideological purity in Czech letters" [o cão de guarda do partido pela pureza ideológica nas letras tchecas] (STEINER, 1982, p. 176). Seus "Artigos e ensaios selecionados" foram publicados em Moscou pela editora Progress em 1982. Sobre isso, ver: KŘíž, 2014, p. 145-148; ANDREAS, 2017. No artigo "Perspectivas contemporâneas do estudo semiótico da arte" (sobre ele cf. adiante), Lótman escreve: "[...] nos anos 1940 e 1950, o estruturalismo na teoria literária foi submetido à crítica também na Tchecoslováquia. Elas foram especialmente agudas no livro de L. Štoll. Este foi elogiosamente resenhado pelo Prof. R. Samárin na revista "Inostránnaia literatura" [Literatura estrangeira], mas não encontrou apoio por parte dos pesquisadores tchecos. Em resenha, F. Vodička observou a unilateralidade da crítica de Štoll (LÓTMAN, 2018, p. 181). Roman Mikháilovitch Samárin (1911-1974) foi um dos principais funcionários da teoria literária soviética oficiosa, doutor em Letras (1948), professor livre-docente (1948), diretor do departamento de história de literatura estrangeira da Universidade de Moscou (1947-1974), entre 1956 e 1961 foi decano da Faculdade de Letras da Universidade de Moscou. Ver ŠTOLL, 1966a (segunda edição de 1972); SAMARIN, 1967; KALIVODA, 1966; SUS, 1967. A resenha de Felix Vodička (VODIČKA, 1966a), publicada na revista Literární noviny [Jornal literário], suscitou a resposta de Štoll (ŠTOLL, 1966b) e uma polêmica se desdobrou nas páginas da mesma revista (ŠTOLL, 1966b), da qual, posteriormente, participaram os discípulos de Mukařovský, o teórico de poesia Miroslav Červenka e o teórico da música Vladimír Karbusický. Para um panorama da polêmica, ver: KŘ́lŽ, 2014, p. 155-158.
}

77 JLSV, f. 4.4, s.n. Datilografado; assinado à mão. A carta é concluída com "felicitações 
Tudo indica que as peripécias descritas estão relacionadas ao estágio das pré-negociações formais e semiformais com a editora. No fundo da editora Iskusstvo no Arquivo Estatal Russo de Literatura e Arte (f. 652) não há quaisquer indícios do projeto da coletânea de artigos selecionados de Mukařovský: não chegou a ser aberta uma pasta sobre a edição do manuscrito, e nas propostas rejeitadas de 1968-1972 os nomes de Lótman, Maliévitch e Mukařovský não são mencionados.

Lótman e Maliévitch começaram o projeto na onda das expectativas dos "anos sessenta", mas alguns anos depois a situação se modificou. Entre os aniversários de 75 e 80 anos de Mukařovský (1966 ${ }^{78}$ e 1971) ocorreu um ponto de virada: as tropas dos países do Tratado de Varsóvia reprimiram a "primavera de Praga" de 1968. Se o aniversário de 75 anos de Mukařovský foi recebido com a publicação de seus artigos estruturalistas e fenomenológicos na Tchecoslováquia, as "notas e artigos publicadas em 1971 na imprensa tcheca tratavam fundamentalmente da atividade social do homenageado". ${ }^{79}$ Talvez a única exceção tenha sido o artigo "O caminho para a estética e teoria da arte dialética", ${ }^{80}$ de Miroslav Káčer, autor que, segundo caracterização de $O$. M. Maliévitch:

tentou revelar o verdadeiro significado contemporâneo dos trabalhos de Mukařovský e mencionou as edições de sua obra que estão sendo preparadas no exterior. Deu informações bastante detalhadas sobre nossa edição em dois vo-

pelo Ano Novo", e o texto fala sobre "Mukařovský e seu jubileu atual na Tchecoslováquia" (isto é, o aniversário de 80 anos de Mukařovský, celebrado em 11 de novembro de 1971). Dessa época são as tentativas infrutíferas de Viatch. Vs. Ivánov de influenciar a editora por meio do diretor do Instituto de Estudos Eslavos, Dmítri Fiódorovitch Márkov, e do presidente do Conselho Científico de cibernética, o acadêmico Aksel Ivánovitch Berg (ver carta de Viatch. Vs. Ivánov a lu. M. Lótman de 20 de dezembro de 1971 e de 6 de janeiro de 1972: TÜR, f. 135, Bc551, fol. 51, 56). Viatcheslav Vsiévolodovitch Ivánov (1929-2017) foi linguista, estudioso literário e semiótico de Moscou, um dos fundadores da Escola Semiótica de Tártu-Moscou. Graças aos esforços dos discípulos de Mukařovský, em 1971, é publicada na Tchecoslováquia a edição por ocasião de seu aniversário de oitenta anos, mas essa publicação em nada contribuiu para promover a edição soviética.

78 Ver a coletânea lançada nesta ocasião: JANKOVIČ, PEŠAT, VODIČKA, 1966.

79 MALIÉVITCH, 2009.

80 KAČER, 1971. 
lumes. ${ }^{81} \mathrm{O}$ cálculo era simples: [...] será que a referência à edição soviética dos trabalhos de Mukařovský não irá impedir a derrota final do neoestruturalismo de Praga? Mas os tempos mudaram. Os serviçais do Papa são agora mais sagrados do que o Papa. [...]

Ao saber do artigo de Káčer sobre a edição que estava sendo preparada na URSS, os ideólogos tchecos protestaram junto os soviéticos e foi emitida uma ordem superior para recusar a edição do livro. Por isso todas nossas tentativas de convencer a editora [...] eram batalhas contra moinhos de vento. ${ }^{82}$

Esse é um episódio característico que demonstra claramente a mudança da política oficial soviética em relação à Tchecoslováquia naqueles anos. No número de outubro de 1968 da principal revista estoniana de letras, Keel ja Kirjandus [Língua e literatura], Lótman publicou em estoniano o artigo "Perspectivas contemporâneas do estudo semiótico da arte" (esse é o título do artigo no original russo; no título estoniano, em lugar de "perspectivas", está tulemusi, isto é, "resultados"). ${ }^{83} \mathrm{O}$ artigo inscreve a semiótica soviética no contexto internacional, principalmente tchecoslovaco, polonês e francês. Contudo a seção dedicada às pesquisas semióticas estruturalistas na Tchecoslováquia não aparece na versão publicada do artigo, na realidade ela foi excluída devido à repressão à Primavera de Praga e à ocupação da Tchecoslováquia pelos países do Tratado de Varsóvia em agosto de 1968. Nessa seção, um espaço significativo foi dedicado aos trabalhos do Círculo Linguístico de Praga e, em particular, aos êxitos teóricos de Mukařovský. O volume em homenagem aos 75 anos de Mukařovský preparado por seus alunos ${ }^{84}$ é muito apreciado e considerado "o resultado da teoria literária estruturalista tcheca" ${ }^{85}$

81 Ver KAČER, 1971, p. 81 e o resumo anexo (ver descrição bibliográfica do artigo). Lótman e Maliévitich tomaram conhecimento do artigo de Kačer (ou, pelo menos, do trecho dele dedicado à edição que estava sendo preparada) antes ainda de sua publicação (ver notas 54 e 59 ).

82 MALIÉVITCH, 2009.

83 LÓTMAN, 1968.

84 Ver referência na nota 71

85 LÓTMAN, 2018, p. 183. 0 texto completo do artigo (seu original em russo) foi publicado 
Miroslav Červenka (1932-2005), aluno de Mukařovský, contou a Peter Steiner em 1979 que, até onde ele tinha conhecimento, o funcionário tcheco com ligações moscovitas que impediu a publicação da edição em dois volumes de Mukařovský foi Ladislav Štoll. ${ }^{86}$ Não foi possível encontrar no arquivo da editora Iskusstvo evidências escritas que confirmem ou refutem essa informação. Os principais correspondentes e confidentes soviéticos de Štoll eram não de Moscou, mas de Leningrado: os pesquisadores da Casa Púchkin, o especialista em literatura tcheca Kirill Ióssifovitch Rovda (1905-1994 ou 1995) e o especialista em literatura do realismo socialista Valentin Arkhípovitch Kovaliov (1911-1999). A correspondência destes com Štoll está guardada no arquivo da Academia de Ciências da Republica Tcheca, contudo ela não fornece nenhum indício sobre o interesse de Štoll pela edição soviética de Mukařovský.

A seleção de artigos de Mukařovský em tradução russa com artigo introdutório de Lótman e comentários de Maliévitch e Lótman só foi publicada em 1994 e 1996, depois da queda da União Soviética e da morte de Lótman; além disso, os dois volumes foram divididos: o primeiro apareceu na série "História da estética em monumentos literários e documentos" da editora Iskusstvo, e o segundo foi publicado dois anos depois pela editora Iazyki Russkoi Kultury. Segundo testemunho de Maliévitch, ${ }^{87}$ "em 1990, [Lótman] ainda teve tempo de examinar e retrabalhar parcialmente" seu artigo introdutório "Jan Mukařovský, teórico da arte". Ele foi publicado postumamente em sua última versão. Essa variante do texto é concluída com o seguinte parágrafo:

Os trabalhos publicados de Mukařovský foram escritos mais de meio século atrás. Sobre eles pode-se dizer justificadamente que sobreviveram à prova do tempo. Ademais, o desenvolvimento impetuoso das pesquisas semióticas entre os anos 1960 e 1980 confirmou o caráter fecundo de suas ideias. No momento presente, sentimos de forma especial-

apenas em 2018 com comentários de nossa autoria (LÓTMAN, 2018, p. 167-206).

86 Como indicado por Peter Steiner em e-mail de 6 de janeiro de 2017 a Igor Pilshchikov. Sobre Štoll ver nota 69.

87 MUKAŘOVSKÝ, 1996, p. 438. 
mente aguda a necessidade de refletir sobre seu desenvolvimento futuro. Nem todas as esperanças foram cumpridas, mas muitas desilusões apressadas também despertam dúvidas. É preciso pensar de forma profunda e imparcial sobre o caminho percorrido. Certa vez, Hegel disse: "O movimento adiante é um retorno ao fundamento primeiro". Na teoria da arte, a obra de Mukařovský é parte desse fundamento primeiro, ao qual hoje parece novamente relevante retornar. ${ }^{88}$

\section{Referências bibliográficas}

AVTONÓMOVA, Natalia. Otkrýtaia struktura: Jakobson - Bakhtin - Lótman - Gasparov. Moscou: ROSSPEN, 2009.

ANDREAS, Petr. "'Celkem značně uklidněn a s chutí do nové práce': Ladislav Štoll v období pražského jara a rané konsolidace”. Česká literatura 65.6, 2017, p. 846-876.

BEASLEY-MURRAY, Tim. "The Mukařovský Case: Structuralism, Stalinism, and the Avant-Garde". Central Europe 13.1/2, 2015, p. 51-71.

BIELÓVA, Galina. Pomináite utchitielei i nastávnikov vachikh... (Pámiati Aleksiéia Fiódorovitcha Lósseva) (Prilojenie k Biulleteniu Biblioteki “Dom A. F. Lósseva”, 15). Moscou: Grand-FAIR, 2012.

ČERVENKA, Miroslav. "Jana Mukařovského rozchod se strukturalismem". Tvar, no 36, 1991, p. 1, 4-5.

BETHEA, David. "Bakhtinian Prosaics versus Lotmanian 'Poetic Thinking': The Code and Its Relation to Literary Biography". Slavic and East European Journal 41.1, 1997, p. 1-15.

DANOW, David. "Bakhtin and Lotman: Novel and Culture". In: Henri Broms, Rebekka Kaufmann (eds.). Semiotics of Culture: Proceedings of the 25th Symposium of the Tartu-Moscow

88 LÓTMAN, 1994, p. 32. Cf.: "[...] o avançar, é retornar ao fundamento, ao primordial e ao verdadeiro". (G. W. F. Hegel, Wissenschaft der Logik [Ciência da lógica], livro 1 (1812), § 1: "Como deve ser feito o começo da ciência?"). No original: "[...] das Vorwärtsgehen ein Rückgang in den Grund, zu dem Ursprünglichen und Wahrhaften ist". 
School of Semiotics, Imatra, Finland, 27th-29th July, 1987. Helsinki: Arator, 1988, p. 233-244.

EGOROV, Boris. Jizn i tvortchestvo Iu. M. Lotmana. Moscou: Nóvoe literatúrnoe obozrênie, 1999.

FLORIÉNSKI, Pavel. "Obrátnaia perspektiva". Utchiónye zapiski Tártuskogo gosudárstvennogo universitieta 198

Trudy po $z$

ákovym sistemam III). Tartu: Universidade de Tartu, 1967 [1922], p. 381-416.

GRZYBEK, Peter. "Bakhtínskaia semiôtika i moskovsko-tártuskaia chkola". In: Permiakov, Ievguéni (ed.). Lótmanovski sbórnik 1. Moscou: IC-Garant, 1995, p. 240-259.

HARTMANN, Nicolai. Estetika. Tradução do alemão. Ed. por A. S. Vasíliev. Moscou: Izdátelstvo inostránnoi literatury, 1958. INGARDEN, Roman. Isslédovania po estétike. Tradução do polonês por A. Iermilov e B. Fiódorov. Moscou: Izdátelstvo inostránnoi literatury, 1962.

IVÁNOV, Viatcheslav Vsévolodovitch. "Pámiati Nikoláia Ióssifovitcha Kónrada". Utchionye zapiski Tártuskogo gosudárstvennogo universitieta 313 (Trudy po vostokovedeniu II2). Tartu: Universidade de Tartu, 1973a, p. 496-499.

IVÁNOV, Viatcheslav Vsévolodovitch. "Znatchénie idei M. M. Bakhtina o znake, vyskázyvanii i dialogue dlia sovremiénnoi semiôtiki". Utchionye zapiski Tártuskogo gosudárstvennogo universitieta 308 (Trudy po znákovym sistemam VI). Tartu: Universidade de Tartu, 1973b, p. 5-44.

JANKOVIČ, Milan; PEŠAT, Zdeněk; VODIČKA, Felix (eds.). Struktura a smysl literárního díla: Janu Mukařovskému k 75. narozeninám. Praga: Československý spisovatel, 1966.

JLSV - Tallinna Ülikool. Juri Lotmani semiootikavaramu [Universidade de Tallinn. Arquivo Semiôtico do Lótman]. Fond 1 (Iu. M. Lótman), fond 4.4 (O. M. Maliévitch).

KAČER, Miroslav. "Cesta $\mathrm{k}$ dialektické estetice a vědě o umění: K osmdesátinám akademika Jana Mukařovského (11. listopadu 1971)". Interscæna: Acta scænographica I.5, 1971, p. 81-85 (texto), p. 85 e 3 o capa (notas); I.6, 1971, p. 120. Os forros no no I.5 
contêm anotações em russo, inglês, francês e alemão.

KALIVODA, Robert. "O tvar a strukturu v slovesném umění". Literární noviny 15.37, 1966, p. 4.

KASSAVIN, Ilia. "M. Bakhtin i Iu. Lótman: U istokov kommunikativno-semiotítcheskogo podkhoda k iazyku i soznaniiu". Filossófskie nauki, no 12, 2007, p. 27-47.

KONDRACHOV, Nikolai (ed.) Prajski lingvistítcheski krujok: Sbórnik statei. Moscou: Progress, 1967.

KŘÍŽ, Michal. Boj o strukturalismus: Archeologie českého literárněvědného strukturalismu. Olomouc: Univerzita Palackého v Olomouci; Edice Qfwfq, 2014.

LÍFCHITS, Mikhail. Ótcherki rússkoi kultury: Iz neízdannogo. Moscou: Nasledie; Fabula, 1995.

LÓTMAN, Iuri [LOTMAN, Juri]. "Kunsti semiootilise uurimise tulemusi tänapäeval". Keel ja Kirjandus, no 10, 1968, p. 577-585.

LÓTMAN, Iuri. Struktura khudójestvennogo tieksta. Moscou: Iskusstvo, 1970.

LÓTMAN, Iuri. "O semiôtiko-estetítcheskom traktate Mukarjóvskogo". Utchionye zapiski Tártuskogo gosudárstvennogo universitieta 394 (Trudy po znákovym sistemam VII). Tartu: Universidade de Tartu, 1975, p. 242.

LÓTMAN [LOTMAN], Iuri. A estrutura do texto artístico. Tradução por Maria do Carmo Vieira Raposo e Alberto Raposo. Lisboa: Estampa, 1978.

LÓTMAN, Iuri. "Jan Mukařovský - teoretik iskusstva". In: Jan Mukařovský, Issliédovania po estetike i teôrii iskusstva. Tradução do tcheco por Viktória Kamiénskaia. Organizado e editado por Iuri Lótman e Oliég Maliévitch. Introdução por Iuri Lótman. Comentários de Iuri Lótman e Oliég Maliévitch. Moscou: Iskusstvo, 1994, p. 8-32.

LÓTMAN, Iuri. O strukturalizme: Raboty 1965-1970 godov. Organizado por Igor Pilshchikov. Ed. com artigos e comentários de Igor Pilshchikov, Nikolai Poseliáguin e Mikhail Trunin. Talim: TLU Press, 2018.

LÓTMAN, Iuri; USPIÉNSKI, Boris. Perepiska 1964-1993. Organizado por Boris Uspiénski. Ed. com comentários de Olga Kel- 
bert e Mikhail Trunin. Talim: TLU Press, 2016.

MALIÉVITCH, Oliég. "Iu. M. Lótman i Jan Mukařovský". Relatório inédito na conferência internacional Fenômenos de Fronteirais Culturais (Os primeiros Dias do Iuri Lótman na Universidade de Talim). Talim, Estónia, 5-7 de junho de 2009.

MUKAŘOVSKÝ, Jan. "Jazyk spisovný a jazyk básnický". In: Bohuslav Havránek, Miloš Weingart (eds.), Spisovná čeština a jazyková kultura. Praga: Melantrich, 1932, p. 123-156.

MUKAŘOVSKÝ, Jan. Kapitoly z české poetiky, segunda edição. Vol. I: Obecné věci básnictví; vol. II: $K$ vývoji české poezie a prózy, vol. III: Máchovské studie. Praga: Svoboda, 1948.

MUKAŘOVSKÝ, Jan. "Kam směřuje dnešní theorie umění?" Slovo a slovesnost 11.2, 1949a, p. 49-59.

MUKAŘOVSKÝ, Jan. Stranickost ve vědě a v umění. Praga: Orbis, 1949b.

MUKAŘOVSKÝ, Jan. "Ke kritice strukturalismu v naší literární vědě". Tvorba 20.40, 4 de outubro 1951, p. 964-966.

MUKAŘOVSKÝ, Jan. "Stalinovy 'Ekonomické problémy socialismu' a literární věda”. Česká literatura 1.2, 1953, p. 53-67.

MUKAŘOVSKÝ, Jan. Z českej literatúry: Štúdie a portréty. Tradução para o eslovaco por Branislav Choma. Bratislava: Slovenský spisovatel', 1961.

MUKAŘOVSKÝ, Jan. Studie $z$ estetiky: Výbor $z$ estetických prací Jana Mukařovského $z$ let 1931-1948. Organizado e com estudo final de Květoslav Chvatík. Introdução por Felix Vodička. Praga: Odeon, 1966.

MUKAŘOVSKÝ, Jan. Kapitel aus der Poetik. Tradução do tcheco por Walter Schamschula. Frankfurt am Main: Suhrkamp, 1967.

MUKAŘOVSKÝ, Jan. "Literatúrnyi iazyk i poetítcheski iazyk". Tradução do tcheco por Aleksandra Chirókova. In: Kondrachov, Nikolai (ed.). Prajski lingvistítcheski krujok: Sbórnik statei. Moscou: Progress, 1967 [1932], p. 406-431.

MUKAŘOVSKÝ, Jan. Kapitel aus der Ästhetik, Tradução do tcheco por Walter Schamschula. Frankfurt am Main: Suhrkamp, 1970a. 
MUKAŘOVSKÝ, Jan. Wśród znaków i struktur: Wybór szkiców. Organizado, editado e com introdução de Janusz Sławiński. Tradução por Jacek Baluch, Maria Renata Mayenowa, Józef Mayen e Lucylla Pszczołowska. Varsóvia: PIW, 1970b.

MUKAŘOVSKÝ, Jan. Cestami poetiky a estetiky. Ed. por Květoslav Chvatík a Bohumil Svozil. Praga: Československý spisovatel, 1971.

MUKAŘOVSKÝ, Jan. "K tchéchskomu perevodu 'Teôrii prozy' Chklóvskogo". Tradução do tcheco por Viktória Kamiénskaia. In: Ievguéni Basin, Mark Poliakov (eds.), Strukturalizm: "za" $i$ "protiv": Sbornik statei. Tradução do inglês, francês, alemão, tcheco, polonês e búlgaro. Moscou: Progress, 1975 [1934], p. 2736.

MUKAŘOVSKÝ, Jan. "Estetítcheskaia fúnktsia, norma i tsennost kak sotsiálnye fakty". Tradução por Viktória Kamiénskaia. Comentários de Oliég Maliévitch. Utchionye zapiski Tártuskogo gosudárstvennogo universitieta 394 (Trudy po znákovym sistemam VII). Tartu: Universidade de Tartu, 1975 [1936], p. 243-295.

MUKAŘOVSKÝ, Jan. Issliédovania po estetike i teôrii iskusstva. Tradução do tcheco por Viktória Kamiénskaia. Organizado e editado por Iuri Lótman e Oliég Maliévitch. Introdução por Iuri Lótman. Comentários de Iuri Lótman e Oliég Maliévitch. Moscou: Iskusstvo, 1994.

MUKAŘOVSKÝ, Jan. Strukturálnaia poétika. Tradução do tcheco por Viktória Kamiénskaia. Organizado e editado por Iuri Lótman e Oliég Maliévitch. Introdução por Iuri Lótman. Comentários de Iuri Lótman e Oliég Maliévitch. Moscou: Chkola "Iazyki rússkoi kultury", 1996.

OTTU゚V SLOVNÍK NAUČNÝ nové doby: Dodatky k velikému Ottovu slovníku naučnému. Praga: J. Otto, 1930-1943, vol. I-VI.

OVSIÁNNIKOV, Mikhail (ed.). Istôria estétiki: Pámiatniki mirovoi estetítcheskoi mysli, em 5 vols. Vol. IV: Estetítcheskie idei narodov Rossii. Estetítcheskie idei narodov Vostótchnoi Evropy XIX - natchala XX veka (domarksistski period). 2a parte. Moscou: Iskusstvo, 1968. 
PALIÉVSKI, Piotr. "O strukturalizme v literaturovédenii". Znamia, no 12, 1963, p. 189-198.

PALIÉVSKI, Piotr. "Mera naútchnosti". Znamia, no 4, 1966, p. 229-236.

PILSHCHIKOV, Igor; POSELIÁGUIN [POSELYAGIN], Nikolai; TRUNIN, Mikhail. "Problemy guénezisa i evoliutsii tártusko-moskóvskogo strukturalizma v rabotakh Iu. M. Lótmana 1960-kh i natchala 1970-kh godov". In: Iu. M. Lótman, O strukturalizme: Raboty 1965-1970 godov. Organizado por Igor Pilshchikov. Ed. com artigos e comentários de Igor Pilshchikov, Nikolai Poseliáguin e Mikhail Trunin. Talim: TLU Press, 2018, p. 7-62.

REID, Allan. Literature as Communication and Cognition in Bakhtin and Lotman. New York, London: Garland, 1990a.

REID, Allan. "Who Is Lotman and Why Is Bakhtin Saying Those Nasty Things about Him?". Discours Social / Social Discourse 3.1/2, 1990b, p. 325-338.

REID, Allan. "The Moscow-Tartu School on Bakhtin". S: European Journal for Semiotic Studies 3.1/2, 1991, p. 111-126.

SAMÁRIN, Roman. "Tsénnaia initsiativa". Inostránnaia literatura, no 12, 1967, p. 262-264.

SEGAL, Dmitri; SENOKOSSOV, Iuri. "Strukturalizm". Filossófskaia entsiklopédia. Vol. 5. Moscou: Izdátelstvo "Sovétskaia entsiklopédia", 1970, p. 144-146.

SHUKMAN, Ann. "Semiotics of Culture and the Influence of M. M. Bakhtin". In: Karl Eimermacher, Peter Grzybek, Georg Witte (eds.), Issues in Slavic Literary and Cultural Theory. Bochum: Brockmeyer, 1989, p. 193-207.

SLÁDEK, Ondřej. Jan Mukařovský: Život a dílo. Brno: Host, 2015.

STEINER, Peter. "The Roots of Structuralist Esthetics". In: Peter Steiner (ed.), The Prague School. Selected Writings, 1929-1946. Austin: University of Texas Press, 1982, p. 174-219.

STEINER, Peter. "From Structuralism to Marxism (and Back?): Jan Mukařovský 1945-1963". Studies in East European Thought 72.1, 2020, p. 1-18. 
SUS, Oleg. "Český strukturalismus z hlediska ideologického 'demaskování.'.' Česká literatura 15.5, 1967, p. 444-452.

SZCZUKIN, Wasilij. "Dukh karnavala i dukh prosveschênia (Bakhtin i Lótman)". Vopróssy filossófii, no 11, 2008, p. 95-129. ŠMAHELOVÁ, Hana. "O vědě, ideologii a strukturalismu". Slovo a smysl 23, 2015, p. 105-114.

ŠTOLL, Ladislav. $O$ tvar a strukturu $v$ slovesném umění: $K$ metodologii a světonázorovým východiskům ruské formální školy a pražského literárního strukturalismu. Praga: Academia, 1966a.

ŠTOLL, Ladislav. "Političnost skutečná a domnělá". Literární noviny $15.48,1966 \mathrm{~b}$, p. 5.

ŠTOLL, Ladislav. "Objektivní historická kritéria". Literární noviny 15.51, 1966c, p. 5.

TITUNIK, Irwin Robert. "M. M. Baxtin (The Baxtin School) and Soviet Semiotics". Dispositio, no 3, 1976, p. 327-338.

TITUNIK, Irwin Robert. "Bachtin and Soviet Semiotics (A Case Study: Boris Uspenskij's Poètika kompozicii)". Russian Literature 10.1, 1981, p. 1-16.

TÜR - Tartu Ülikooli Raamatukogu. Käsikirjade ja haruldaste raamatute osakond (Biblioteca da Universidade de Tartu. Departamento de Manuscritos e Livros Raros). Fond 135 (Iuri Lótman, Zara Mints. Arquivo epistolar), fond 136 (Iu. Lótman. Arquivo particular).

USPIÉNSKI, Boris. Poétika kompozitsii: Struktura khudójestvennogo teksta i tipolôgia kompozitsiônnoi formy. Moscou: Iskusstvo, 1970.

USPIÉNSKI, Boris. A poética da composição: Estrutura do texto artístico e tipologia das formas com positivas. Tradução por Marta H. Kirst e Maria da Glória Bordini. Porto Alegre: Curso de Pós-Gradução em Letras da PUCRS, 1981.

VACHEK, Josef. Lingvistítcheski slovar Prajskoi chkoly. Tradução do francês, alemão, inglês e tcheco par Igor Meltchuk e Vladímir Sánnikov. Editado e prefaciado por Aleksandr Reformatski. Moscou: Progress, 1964.

VODIČKA, Felix. "Ne jen jubilejně". Literární noviny 15.41, 
1966a, p. 5.

VODIČKA, Felix. "Kritéria historického hodnocení". Literární noviny $15.48,1966 \mathrm{~b}, \mathrm{p} .5$.

VODIČKA, Felix. "Subjektivistická zaslepenost". Literární noviny $16.2,1967$, p. 3.

ZELENKA, Miloš. "Jan Mukařovský, Frank Wollman a literární věda na přelomu 40. a 50 . let 20 . století : úskalí cesty mezi strukturalismem a stalinismem". Slavica litteraria 15.2, 2012, pp. 157-167.

Traduzido por Priscila Nascimento Marques ${ }^{89}$

Recebido em 29/07/2021

Aceito em 16/08/2021 